\title{
Effect of Tillage Methods on Soil Properties and the Yield of Watermelon (Citrullus lanatus)
}

\section{Suleiman $\mathbf{A A}^{\mathbf{1}}{ }^{*}$, Yit Arn Teh ${ }^{\mathbf{1}}$, Ella $\mathrm{FA}^{\mathbf{2}}$ and Ejeanobi $\mathrm{IF}^{\mathbf{3}}$}

${ }^{1}$ School of Natural and Environmental Sciences, Faculty of Science, Agriculture and

Engineering, Newcastle University, Newcastle Upon Tyne, UK

${ }^{2}$ Department of Biological Science Education, Federal College of Education

(Technical), Umunze, Anambra State, Nigeria

${ }^{3}$ Department of Agricultural Science Education, Federal College of Education

(Technical), Umunze, Anambra State, Nigeria

*Corresponding Author: Suleiman AA, School of Natural and Environmental

Sciences, Faculty of Science, Agriculture and Engineering, Newcastle University,

Newcastle Upon Tyne, UK.

DOI: 10.31080/ASAG.2020.05.0943
Received: December 05, 2020

Published: January 16, 2021

(C) All rights are reserved by Suleiman AA.,

et al.

\begin{abstract}
Tillage methods as a soil management practice improves crop quality and yield. An experiment was conducted in the 2019 dry season-farming, to evaluate the effect of tillage methods on soil properties and the yield of watermelon (Citrullus lanatus) in the department of Agricultural science education, student demonstration farm; of the Federal College of Education (Technical), Umunze, Anambra State. Nigeria. The experiment consisted of three tillage methods (Ridge, Flat and Bed) with three replicates in a ( $3 \times 1)$ factorial experiment. Tillage effects of plots under the flat (F) method performed significantly $(p<0.05)$, with a total number of 40 friuts. The Flat (F) tillage method equally produced the highest mean fruit size of $(18 \mathrm{~cm})$ as compared to bed (B) and the ridge (R) tillage method. Consequently, watermelon fruits under the bed (B) method of tillage had the highest mean fruit weight of (6.2kg), which was significantly different from mean weight obtained under the flat (F) and the ridge (R) methods of tillage. Planting on the flat (F) produced significantly higher number of fruits and size compared to planting on the bed and ridge. Therefore, both the flat and the bed methods of tillage has the potential for watermelon production in terms of number of fruits, fruit size and weight respectively in the study area.
\end{abstract}

Keywords: Tillage Methods; Ridge (R); Flat (F); Bed (B)

\section{Introduction}

Watermelon (Citrullus lanatus) belongs to the family Cucurbitaceae which includes squash, pumpkin and cucumber. It is a popular dessert vegetable, with year-round availability. Watermelons vary in shape, from globular to oblong. External rind colour varies from light to dark green and may be solid, striped or marbled. The pulp colour of most commercial varieties is red. The fruit is generally eaten raw. Watermelon has very high-water content $(93 \mathrm{ml} / 100 \mathrm{~g}$ edible portion). It is rich source of carbohydrates, minerals and vitamins. It contains carbohydrates (5mg), calcium (8mg), phosphorous ( $9 \mathrm{mg}$ ), ascorbic acid ( $8 \mathrm{mg}$ ) and vitamins ( $0.64 \mathrm{~g}$ ) per $100 \mathrm{~g}$ of edible portion. Watermelons grow best on non-saline sandy loam soils. Light-textured fields warm up faster in the spring and are therefore favored for early production. Therefore, sandy and loamy soil is suitable for growing watermelons. Ideal to grow in neutral to slightly acidic soil (soil pH is around 6-6.8) Avoid compact, clayey soils [1]. 
Soil tillage is among the important factors affecting soil physical properties such as temperature, moisture, bulk density, aggregation, organic matter content, and plant morphology such as root density. Among the crop production factors, tillage contributes up to $20 \%$ [2]. Tillage method affects the sustainable use of soil resources through its influence on soil properties [3]. The proper use of tillage can improve soil related constrains, while improper tillage may cause a range of undesirable processes, e.g. destruction of soil structure, accelerated erosion, depletion of organic matter and fertility, and disruption in cycles of water, organic carbon and plant nutrient [4]. Use of excessive and unnecessary tillage operations is often harmful to soil. Therefore, currently there is a significance interest and emphasis on the shift to the conservation and no-tillage methods for the purpose of controlling erosion process [5].

Conventional tillage practices modify soil structure by changing its physical properties such as soil bulk density, soil penetration resistance and soil moisture content [6]. Annual disturbance and pulverizing caused by conventional tillage produce a finer and loose soil structure as compared to conservation and no-tillage method which leaves the soil intact $[7,8]$. Therefore, conservation tillage may reduce disruption of continues pores. Whereas, conventional tillage decreases soil penetration resistance and soil bulk density [8]. Tillage method affects the sustainable use of soil resources through its influence on soil properties as it improves porosity and water holding capacity of the soil. Continuity of pore network is also interrupted by conventional tillage, which increases the tortuosity of soil. This all leads to a favourable environment for crop growth and nutrient utilization for the optimal productivity of crops.

\section{Statement of problem}

The effect of tillage methods on soil properties' change the way in which crops respond to nutrition and fertility management practices. Therefore, the present evaluation and assessment, was carried out to ascertain the effect of tillage methods on soil properties and the yield of watermelon (Citrullus lantatus), in the department of Agricultural science education, student demonstration farm, of the Federal College of Education (Technical), Umunze, Anambra State. Nigeria.

\section{Objectives}

The objectives of the study:

- To evaluate the effect of tillage methods on the number of water melon fruits.

- To investigate the effect of tillage methods on the fruit size (circumference) of watermelon fruits.

- $\quad$ To asses the weight of watermelon fruits as affected by tillage methods.

\section{Materials and Methods}

Experimental location

The field were carried out during 2019 dry season. at the student demonstration farm, federal college of Education (Technical), Permanent-site Umunze, Orumba south Local Government area of Anambra State. The area lies between latitude $5^{0} 33^{\prime} 46^{\prime \prime} \mathrm{N}$ and longitude $7^{0} 15^{\prime} 78^{\prime \prime} \mathrm{E}$. South east of Nigeria is at Latitude $5^{0} 34^{\prime} \mathrm{N}$ and Longitude $7^{0} 54^{\prime} \mathrm{E}$ east of the Greenwich meridian.

The area falls within the semi-deciduous (derived savanna) forest zone of Nigeria [9]. This zone is characterized by two rainy seasons and two dry seasons in a year; federal ministry of agriculture and rural development (FMARD (2010), the major rainy season starts from March to July and the minor rainy season starts from September to November. There is a short dry period in August. The major dry season occurs between the end of the minor wet season and the next major wet season (November to March). Rainfall distribution is bimodal with peaks in June and September. The mean annual precipitation exceeds $2000 \mathrm{~mm}$. Temperatures are generally low and uniform throughout the year. The mean monthly temperatures range from $21.3-30^{\circ} \mathrm{C}$. Relative humidity is generally high in the mornings being about $90 \%$ at 600 hours and falling to between 60 and $75 \%$ in the afternoon (1500 hours). Generally, in the wet season relative humidity is high (about $95 \%$ ) while it is low (about $40 \%$ ) in the dry season [10].

The vegetation in the study area is derived savannah, which is characterised by grasses such as elephant grass (Pennisetum purpureum), guinea grass (Pannicum maximum), spear grass (Impe- 
rata cylindrical), etc. The soil of the area is an Alfisol, and classified under soil series $[9,11]$. Alfisol are soil orders in the USDA (United States Department of Agriculture) soil taxonomy. In the FAO classification, most Alf refers to Aluminium (Al) and Iron (Fe). They are soils formed in semi-arid to humid areas, typically under a hardwood forest cover. They are mineral soils with surface horizon which is too thin or too light coloured (Ochric epipedon) to be classified as a Mollic epipedon (thick dark coloured not highly leached surface horizon) [12].

\section{Plot size}

Watermelon (Citrullus lanatus) seeds were sown on the field at 2seed per drill. Each plot size measured $4.0 \mathrm{~m}$ x $3.0 \mathrm{~m}\left(12 \mathrm{~m}^{2}\right)$, while plant spacing was $20 \mathrm{~cm} \times 30 \mathrm{~cm}$ with plant population of 144 plants/ha.

\section{Treatments combination}

The treatments comprised of three tillage methods (Ridge, Bed and Flat).

- $\quad$ R: Ridge

- B: Bed

- F: Flat

Soil sampling and preparation

Soil samples were taken across the experimental field to a depth of $30 \mathrm{~cm}$ randomly and bulked for laboratory analysis. The soil samples were air dried under ambient temperature at the soil science laboratory. The soils were crushed using a mortar and pestle and then sieved through a $2 \mathrm{~mm}$ mesh. The sieved samples were stored in polythene bags and taken to the laboratory for chemical and physical analysis at the Department of Agronomy University of Ibadan. Ibadan Nigeria.

- $\quad$ Experimental design and layout: Three treatments $(3 \times 1)$ Tillage by fertilizer combination was laid out in a Randomized Complete Block design (RCBD) with three replications.
- Data collection: Plant vine length were taken at 3weeks after sowing, while number of fresh fruits, weight and circumference of fruits were determined using 10 fruits per plot.

- Statistical analysis: The data collected were subjected to analysis of variance (ANOVA) using SAS edition 8.2 and significant differences among the treatment means were separated using least significance difference (LSD) at 5\% level of probability.

Results

\begin{tabular}{|c|c|}
\hline Soil properties & Soil test value \\
\hline $\mathrm{pH}\left(\mathrm{H}_{2} \mathrm{O}\right)(1: 2: 5 \mathrm{~h}$ & 6.3 \\
\hline Organic Carbon $(\%)$ & 9.5 \\
\hline Total Nitrogen $\left(\mathrm{g} \mathrm{kg}^{-1}\right)$ & 1.5 \\
\hline Available Phosphorus $\left(\mathrm{mg} \mathrm{kg}^{-1}\right)$ & 9.0 \\
\hline Exchangeable Cations $\left(\mathrm{cmol} \mathrm{kg}^{-1}\right)$ & \\
\hline $\mathrm{Ca}$ & 1.8 \\
\hline $\mathrm{Mg}$ & 1.5 \\
\hline $\mathrm{K}$ & 0.1 \\
\hline Na & 0.4 \\
\hline Exchangeable Acidity $\left(\mathrm{cmol} \mathrm{kg}^{-1}\right)$ & 0.5 \\
\hline Effective C.E.C $\left.(\mathrm{cmol} \mathrm{kg})^{-1}\right)$ & 4.2 \\
\hline Mechanical analysis $\left(\mathrm{g} \mathrm{kg}^{-1}\right)$ & \\
\hline Sand & 709 \\
\hline Silt & 181 \\
\hline Clay & 110 \\
\hline Textural Class $\left(\mathrm{USDA}^{\mathrm{N}}\right)$ & Sandy Loam \\
\hline
\end{tabular}

Table 1: Chemical Properties of soil and particle size distribution.

Table 1 shows the result of the pre-cropping soil physio-chemical properties.

Means with the same letter along the columns indicates no significant difference at 5\% Probability level. 


\begin{tabular}{|c|c|c|c|}
\hline $\begin{array}{c}\text { Tillage } \\
\text { Methods }\end{array}$ & $\begin{array}{c}\text { Number of } \\
\text { fruits }\end{array}$ & $\begin{array}{c}\text { Mean fruit } \\
\text { size (cm) }\end{array}$ & $\begin{array}{c}\text { Mean fruit } \\
\text { weight (kg) }\end{array}$ \\
\hline Ridge (R) & $26 \mathrm{~b}$ & $12 \mathrm{c}$ & $5.8 \mathrm{~b}$ \\
\hline Bed (B) & $29 \mathrm{~b}$ & $16 \mathrm{~b}$ & $6.2 \mathrm{a}$ \\
\hline Flat (F) & $40 \mathrm{a}$ & $18 \mathrm{a}$ & $5.8 \mathrm{~b}$ \\
\hline
\end{tabular}

Table 2: Effect of tillage methods and yield of watermelon at total harvest.

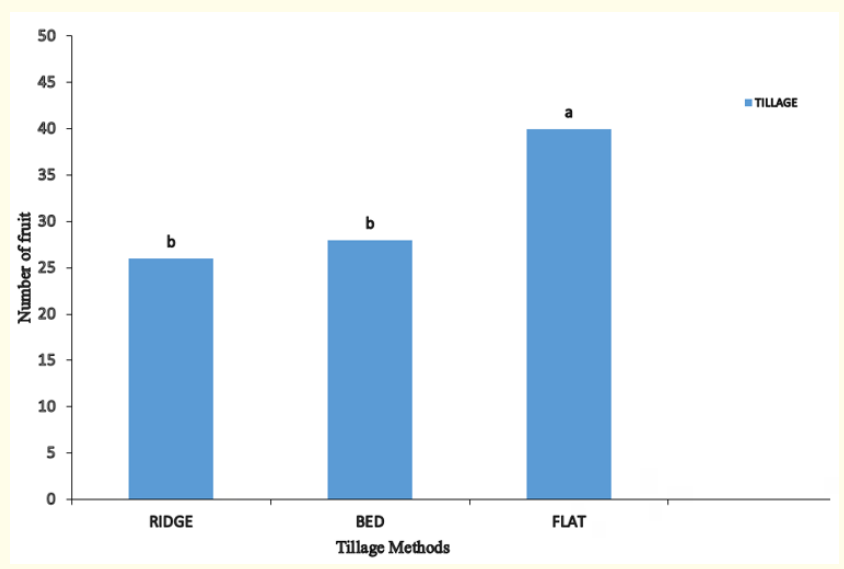

Figure 1: Effects of tillage methods on number of water melon fruit.

Key: R- Ridge, B- Bed, F- Flat.

Means with the same letter along the bars indicates no significant difference at 5\% Probability level.

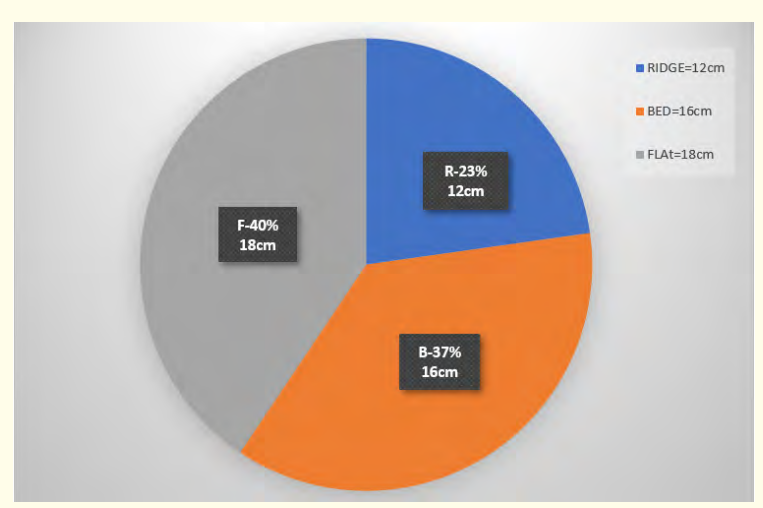

Figure 2: Effects of Tillage methods on the \% mean fruit size $(\mathrm{cm})$ of water melon fruits.

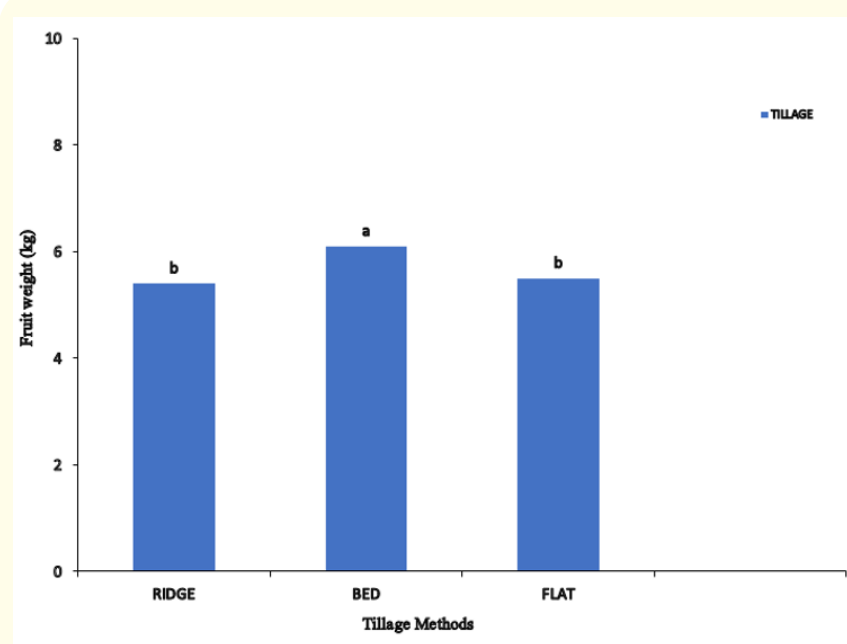

Figure 3: Effects of tillage methods on the weight $(\mathrm{kg})$ of water melon fruits.

Key: R- Ridge, B- Bed, F- Flat.

Means with the same letter along the bars indicates no significant difference at 5\% Probability level.

\section{Discussion}

Physical and chemical properties of soil used for the experiment

The soil of the experimental site is an Alfisol, locally classified under Iwo soil series $[9,13]$. The result (Table 1), showed that the $\mathrm{pH}$ of the soil was slightly acidic with a $\mathrm{pH}$ value of (6.3). Organic carbon value of $9.5 \mathrm{~g} \mathrm{~kg}^{-1}$ was greater than the critical level of $8.7 \mathrm{~g}$ $\mathrm{kg}^{-1}$ for the soil in South-eastern Nigeria (Sobulo and Akamigbo). The total nitrogen content of $1.5 \mathrm{~g} \mathrm{~kg}^{-1}$ was at the critical level of 1.5 $\mathrm{g} \mathrm{kg}^{-1}[14]$. While the available P of $9.0 \mathrm{mg} \mathrm{kg}^{-1}$ was below the critical level of 10 - $16 \mathrm{mg} \mathrm{kg}^{-1}$ [15]. The $\mathrm{K}$ status of the soil which was $0.1 \mathrm{c}$ mol kg-1 also less than the critical level of $0.2 \mathrm{c} \mathrm{mol} \mathrm{kg}^{-1}$ [16]. Effective cation exchange capacity (ECEC) was $4.2 \mathrm{c} \mathrm{mol} \mathrm{kg}^{-1}$. Mechanical analysis of the soil revealed a sand fraction of $715 \mathrm{~g} \mathrm{~kg}^{-1}$, silt 182 $\mathrm{g} \mathrm{kg}^{-1}$, and clay $103 \mathrm{~g} \mathrm{~kg}^{-1}$ respectively, classified as sandy loam according to the USDA classification. 
Effects of tillage methods on the number of watermelon fruits depicted in figure 1, table 2: Shows that the flat (F) method of tillage produced higher number of fruits (40), compared with the bed (B) and ridge (R) tillage method respectively. The flat (F) method of tillage produced a significantly $(\mathrm{P}<0.05)$ higher fruit yield, while the ridge method $(\mathrm{R})$ produced a significantly lower fruit yield. This maybe due to absence of tillage practice (zero) which induced close contact of soil particle and equally allows for rapid growth or spread of vines of the crop on field without any hindrance, as the soil surface was disturbed minimally as described by Bergmann [17]. Babalola and Olaniyi [18] reported significantly lower number of watermelon fruits, with conventional tillage system compared to the zero (flat) tillage system in the derived savannah. Ridge (R) system of tillage is the major types of conventional tillage methods adopted in Nigeria localities, in these studies, planting on the flat (F) produced significantly higher number and fruits size compared to planting on the bed and ridge.

Effects of Tillage methods on mean fruit size $(\mathrm{cm})$ of watermelon fruits figure 2, table 2 shows that the mean size of watermelon fruits as expressed in terms of circumference of a circle was significantly increased in the following order $(\mathrm{R}-12 \mathrm{~cm}>\mathrm{B}-16 \mathrm{~cm}>$ $\mathrm{F}-18 \mathrm{~cm})$. It is found that watermelon fruits size under the flat (F) tillage system had the largest mean fruit size as compared to ridge and bed methods of tillage.

Effects of tillage methods on the mean weight $(\mathrm{kg})$ of watermelon fruits, depicted in figure 3 , table 2 shows that plots under the bed (B) method of tillage, had the highest mean fruit weight of (6.2kg). This was significantly higher at $(p=0.05)$, compared with the weight of fruits produced under the flat $(F)$ and ridge $(R)$ tillage method respectively [19-22].

\section{Conclusion}

Effect of tillage methods on soil properties and the yield of watermelon (Citrullus lanatus) experimental results, it is concluded that the flat $(F)$ method of tillage as a conservational form of tillage with a minimal soil disturbance, proved superior to the ridge (R) and bed (B) methods in terms of its effects on number of water melon fruits and fruit size. With respect to bed (B) method of tillage, performed significantly in terms of mean weight of water- melon $(6.2 \mathrm{~kg})$ as compared to flat $(\mathrm{F})$ and the ridge $(\mathrm{R})$ methods. This shows that both the flat and the bed methods of tillage has the potential for watermelon production in the study area.

\section{Recommendations}

- $\quad$ For optimal performance of watermelon in the study area, there is need to augment soil native nutrients with compost manure as to make up for the level of Phosphorous and Potassium ( $\mathrm{P}$ and $\mathrm{K}$ ) which was below critical level for soil of the south- eastern Nigeria.

- There is need to also check mate the impact of soil erosion in the study area with the use of compost manure, so as to build up more stable soil aggregates in combination with appropriate tillage methods (which should be alternated, depending on the watermelon production season)

- A soil testing programme is essential before fertilizer application and organic matter management is key to the sustainable vegetable production in these soils.

\section{Bibliography}

1. Jim Shrefler and Eric Rebek. "Watermelon (Citrullus lenatus) is one of the most important vegetable crops of Nigeria and is well adapted to its soil and climati condition Ext". Journal of Agricultural and Environmental 2 (2014): 8-13.

2. Khurshid K., et al. "Effect of tillage and mulch on soil physical properties and growth of pepper". International Journal of Agriculture and Biology 5 (2006): 593-596.

3. Hammel JE. "Long term tillage and crop rotation effects on bulk density and soil impedance in northern Idaho". Soil Science Society of America Journal 53 (1989): 1515-1519.

4. Lal R. "Tillage effects on soil degradation, soil resilience, soil quality and sustainability". Soil and Tillage Research 51 (1993): 61-70. 
5. Iqbal M., et al. "Residual effect of tillage and farm manure on some soil physical properties and growth of wheat (Triticum aestivum L.)". International Journal of Agriculture and Biology 1 (2005): 54-57.

6. International Institute of Tropical Agriculture, Ibadan Nigeria. (IITA). "Long term conventional and no tillage effects on selected soil physical properties". Soil Science Society of America Journal 54 (2013): 161-166.

7. Rashidi M and F Keshavarzpour. "Effect of different tillage methods on grain yield and yield components of maize (Zea mays L.)". International Journal of Agriculture and Biology 2 (2017): 274-277.

8. Khan FUH., et al. "Intrinsic implication of different tillage practices on soil penetration resistance and crop growth". International Journal of Agriculture and Biology 1 (2001): 23-26.

9. Smyth AJ and Montgomery RF. "Soils and Land use in Nigeria". The govt. of Nigeria. Ibadan (1962): 50.

10. Federal ministry of Agriculture and rural development. Nigerian reference base for soil Fertilizer Research 6 (2010): 65-71.

11. Suleiman AA., et al. "Characterization and classification of soils on one toposequence at the federal college of education (Tecnical), Umunze South eastern Nigeria" (2015).

12. Woomer PL., et al. "The importance and management of soil organic matter in the tropics". In: Woomer, P.L., and Swift, M.J. (Eds.), The Biological Management of Tropical Soil Fertility (2010).

13. Suleiman AA., et al. "Effects of tillage and Terminalia catappa L. leaf compost on soil properties and performance of Capsicum chinense Jacq". 3 (2015): 73-82.

14. Enwenzor WO., et al. Fertilizer use and management practices for crops in Nigeria (series No 21) produced by Fertilizer Procurement and Distribution Division of the Fed. Ministry of Agriculture, Water Res and Rural Dev., Lagos (2013).

15. Agboola AA and Unamma PA. "Maintenance of soil fertility under traditional farming systems in: Lombin et al. (eds) Organic fertilizer in the Nigerian Agriculture, present and future". Proceedings of a National Organic Fertilizer Seminar, Kaduna, Nigeria. March 26-27, 1991 (2010).
16. Adeoye GO and Agboola AA. "Critical levels for soil $\mathrm{pH}$, available $\mathrm{P}, \mathrm{K}, \mathrm{Zn}$ and maize ear leaf content of $\mathrm{P}, \mathrm{Cu}$ and $\mathrm{Mn}$ in sedimentary soils of South eastern Nigeria" (2013).

17. Bergmann W. "Nutritional disorders of plants". 2nd ed. Gustav Fischer Verlag, Jena, Germany (2013).

18. Babalola $\mathrm{O}$ and Olaniyi V O. "Conventional and conservational tillage practices on Nigeria tropical soils". Soil Science 126.5 (2012): 269-278.

19. FAO. Soil Classification and Scaling soil nutrient balances. FAO Fertilizer and Plant Nutrition Bulletin No. 15. United Nations (FAO-UN) (2004).

20. Kogbe J O S and Adediran J A. "Influence of nitrogen, phosphorus and potassium application on the yield of pepper in the savannah zone of Nigeria". African Journal of Biotechnology 2 (2003): 345-349.

21. Ohiri AC and Ezumah AC. "Tillage effects on cassava production and some soil properties". Soil and Tillage Research 17 (2002): 221-231.

22. Subolu IO and Akamigbo. "Critical levels for soil organic matter $\mathrm{pH}$, available P.K.Zn and maize ear leaf content of $\mathrm{P}, \mathrm{Cu}$ and Mn in sedimentary soils of South eastern Nigeria". Fertilizer Research 6 (2005): 65-71.

\section{Assets from publication with us}

- Prompt Acknowledgement after receiving the article

- Thorough Double blinded peer review

- Rapid Publication

- Issue of Publication Certificate

- High visibility of your Published work

Website: www.actascientific.com/

Submit Article: www.actascientific.com/submission.php

Email us: editor@actascientific.com

Contact us: +919182824667 